\title{
The Role of Psychological Actions in Combat Crime Prevention Efforts
}

\author{
Fitri Yani $^{1 *}$, Alvi Syahrin ${ }^{2}$, Madiasa Ablizar ${ }^{3}$, M Eka Syahputra ${ }^{4}$ \\ ${ }^{1}$ Universitas Sumatera Utaral \\ ${ }^{2}$ Universitas Sumatera Utara 2 \\ ${ }^{3}$ Universitas Sumatera Utara 3 \\ ${ }^{4}$ Universitas Sumatera Utara4 \\ Email: pidana80@gmail.com ${ }^{1}$, alviprofdr@usu.ac.id, ${ }^{2}$ ablisar@vahoo.co.id, ${ }^{3}$ m.ekaputra@usu.ac.id. ${ }^{4}$
}

\begin{abstract}
Crime prevention in Indonesia is usually carried out by law enforcers by using and implementing criminal law regulations stipulated in the Criminal Code or based on laws and regulations outside the Criminal Code. This has been widely practiced in the scope of law enforcement, both in the police and in the judiciary. for assistive science in law enforcement or in responding to and uncovering legal cases that exist in the community often apply psychological aids in conducting examinations of cases at the police level and even at the court level where the judge will give his decision for a particular case. In particular, what is currently happening is that the punishments given are imprisonment, fines, confinement which is regulated in the provisions of the criminal law, namely the Criminal Code. What will be discussed is how the role of psychological action in efforts to overcome crime through psychological actions taken in the application of punishment, namely when a crime has occurred, whether psychological action can help in efforts to overcome crime. The problems in this study are: 1) what is the role of psychological action to combat crime prevention efforts? 2) How is the implementation of psychological measures in practice in some cases? This legal research belongs to the normative-empirical, using primary data and secondary data, namely by conducting library research and field research, library research, especially related books, laws and regulations, while field research is research conducted with direct observation (observation). and direct interviews with directly related samples. Conducted through psychological interviews and psychological tests, psychotherapy or counseling, creating therapy or training programs, and hypnosis therapy for criminal law reform in the future.
\end{abstract}

Keywords: Role, Psychological, Crime.

\section{INTRODUCTION}

As a legal state, the role of law has a main role and position if the law can place its function as protection to protect the community from the threat of danger and harmful actions that come from each other and the community, including those from the government and those from outside. aimed at the physical, mental, health, values and human rights, and provide justice in the form of mutual care and protection and provide justice to the community. [1] Thus, the law is used as a tool in determining the direction of goals, and the direction of development in a fair manner, meaning that the law is also used as a tool and direction of development and as a means of control for fairer development. This legal function is carried out in order to achieve the objectives outlined in our constitution, namely to protect the entire Indonesian nation and the entire homeland of Indonesia. Based on this, the government's task is to create social instruments to protect the entire Indonesian nation from various actions that cause harm. Implementation of requirements through social instruments such as the creation of legal norms should pay attention to social developments in society itself by providing certainty and predictability to actions that are expected to cause serious social problems, for example efforts to overcome the spread of crime, which is why prevention and creation policies (policy/criminal) must be carefully calculated and implemented consistently. [2]

It should be remembered that the most basic purpose of criminal law is to improve people who have committed crimes so that they do not repeat their actions, which by law becomes a necessity in the life of the nation and state, because law can create order and justice in society, with renewed criminal penalties. by applying the provisions of criminal law outside the Criminal Code and other laws are expected to be able to change a person's behavior. For this reason, the form of action that can be taken to prevent crime is to be 
supported by the help of other sciences, both to prove wrongdoing and for behavior as well as to change behavior in order to prevent future crimes, for example psychological assistance by applying psychological actions concerning behavior. humans and human actions. This proves that criminal law cannot stand alone in preventing and eradicating crime. In this case, the help of other sciences is needed. [3]

In revealing a case, a law enforcer applies the science of legal psychology in the investigation process. At the handling stage (disclosure through investigation and investigation), namely when a crime has occurred, legal psychology can assist the police in identifying the perpetrator and the motive of the perpetrator, so that they can catch the culprit. And psychological measures should also be applied in order to pay attention to the psychological side of the perpetrator at the criminalization stage, the criminal act formulation system, the criminal liability formulation system, the criminal sanction formulation system and the formulation of sentencing guidelines. However, in terms of tackling crime in terms of psychological actions, it has not been carried out or has not been consistently implemented, because in the enforcement and prevention of criminal acts using penal and non-penal criminal law policies but not yet in the form of psychological actions. This can be seen in terms of fines, imprisonment, and confinement sanctions, the form of this policy is preventive efforts focused on prevention and repressive efforts focused on prevention. The implementation of these efforts has not run optimally due to several things, namely lack of counseling and socialization, lack of cross-sectoral coordination, people who lack legal awareness and people prefer to pursue peace. This is a benchmark for reforming criminal law, but with the enactment of penalties in lieu of fines in the form of criminal work training, it does not change the behavior of children in dealing with the law and further increases the level of crimes committed by children. This is the problem formulation in this study, namely: 1) what is the role of psychological action to combat crime prevention efforts? 2) how is the implementation of psychological measures in practice in criminal cases? There are weaknesses and shortcomings in the application of criminal law for crime prevention. Currently there is a need for a criminal law policy in an effort to overcome criminal acts such as psychological actions that are expected in the future in national criminal law efforts. For the prevention of crime. This study aims to examine the main problems regarding the role of psychological measures in efforts to tackle crime, and how to implement psychological measures in practice in several existing and running cases. This issue was developed into two research questions related to the role of psychological measures in efforts to tackle crime and the implementation of psychological measures in practice in several cases in the context of overcoming crimes in Indonesia.

\section{RESEARCH METHOD}

This legal research belongs to uses empirical juridical research methods, which in other words is a type of sociological legal research that examines how the law is implemented in society. Or in other words research that looks at the conditions that occur in the community. With the facts and existing data to solve existing problems. Legal materials, especially primary legal materials and secondary legal materials, are also used to understand law as a set of positive rules or norms in the legal system that regulates human life and by understanding law as a set of rules or positive norms in the legal system that regulates human life and conducting library research, field research, library research, namely research conducted by examining library materials, especially related books, legislation, while field research is research carried out by direct observation (observation) and interviews directly with directly related samples. [4]

\section{FINDING AND ANALYSIS}

\subsection{Psychological Action}

Legal psychology is a branch of legal study method that is still young which was born because of the need and demand for the presence of psychology in legal studies, especially the need for law enforcement practices, including for the purpose of examination before a court trial. several definitions of legal psychology found in various literatures; As a form of psychological services carried out in law, including Psycho-Legal Issues, assistance in court and criminal behavior (The Commite On Etnical Guidelines For Forensic Psychology), 2. In Blackburn, states that legal psychology includes legal issues; research in testimony, research on jury and judge decision-making, as well as in criminology to determine the causes, preventive, curative measures, criminal behavior and assistance in court carried out by experts in court;3. According to Curt R. Bartol, that legal psychology covers aspects of human behavior in the legal process, such as the memory of witnesses, decision-making by jurors and even perpetrators; 4. An approach that emphasizes human determinants of law, including legislation and judges' decisions, which emphasizes the individual as the unit of analysis. The main concern of the study of legal psychology is more focused on the law enforcement process (eyewitnesses, suspects/defendants, criminal victims, public prosecutors, lawyers for judges and convicts); 5. Quoting the opinion of Edward E Jones on social psychology in the book Abitoro Prakoso, Legal psychology is a study of the nature, function, and legal behavior of the mental experience of individuals in relation to various legal phenomena; [5] 6. Psychology and law is a relatively young field of scholarship. Connceptualized broadly, the field 
encompases diverse approaches to Psychology. Each of major Psychologycal suddivisions has contibuted to research on legal issues: cognitive (e.g.eyewitnes testimony), developmental (e.g., children testimony), social (e.g., jury behavior), clinical (e.g, assesment of competence), biological (e.g, the polygraph), and industrial organizational psycology and law). (Psychology and law are relatively young fields of scholarship. Broadly linked, these fields cover a wide variety of approaches to Psychology. Each of the major Psychological restorers has contributed to research on legal issues: developmental cognitive testimony (e.g. testimony of children), social behavior (eg, jury behavior), clinical (eg, competency assessment), biological (eg, polygraph), and psychology and industrial organization law); 7. legal issues involves empirical,psychology research of the law, legal institution, and people who come into contant with the law. Legal Psychologist typically take basic social and cognitive theories and principles and apply them to issues in the legal system such as eyewitness memory, jury decision making, investigation, and interviewing. The term "legal Psychology" has only recently come into usage, primarily as a way to differentiate the experimental focus of legal Psychology from the clinically-oriented forensic Psychology.[6]

The application of psychology in the legal field which is related to its functions and roles as described above is basically related to the human rights of suspects whose freedom is being restricted. In accordance with the definition of psychology, it is actually humans who are most interested in psychology, in other words humans really need psychology in their daily lives in various fields. Given that the law itself is also a behavior in terms of certain aspects, psychology can also be applied in the settlement of a criminal act.[7] This can be seen from the role of psychology in law. According to Farrington and Hawkins, what is meant by legal process here is the process of examining or interrogating suspects at the investigation level. Psychology has a very big role in this process because psychology looks at the background of the behavior and actions of the individual being examined. Investigators who have at least a little knowledge of psychology can easily identify the character and personality of the suspect, so that appropriate approach techniques can be determined for a successful investigation that takes place in a humane manner.[8]

\subsubsection{The Role of Psychological Actions Crime Combat Prevention Efforts.}

Mistakes in thinking can also lead to the emergence of a crime. Deviant behavior is based on a wrong understanding of how to meet basic needs and instincts. Irrational and destructive thinking can lead to emotional-behavioral disorders. However, the controversy surrounding the source of the emergence of errors of thought is still debated by scientists. Therefore, psychological programs related to their application in the field of law play a role in cognitive restructuring (correcting wrong ways of thinking).[9] The criminal law formulation policy that takes into account the criteria for criminalization, conducts comparative studies, uses a policy approach and a value approach and aims to achieve public welfare, is expected to produce a law product that is more effective and efficient in efforts to overcome and eradicate crime in the community. ${ }^{[10]}$

The existence of limited penal facilities requires the use of non-penal facilities more optimally, because it can eliminate the causes of crime. In addition, non-penal means can be more effective because they are preventive in nature, while penal facilities are more repressive in nature, namely taking action and eradicating after the crime has occurred. ${ }^{[1]}$ The role of psychological actions that can be taken in tackling crime is to carry out CBT cognitive restructuring activities, which these activities are carried out in the form of; 1 . Regarding efforts to straighten out the thinking of criminals who are 'already' wrong, this activity aims to provide a stimulus to the community, both perpetrators and defendants by providing religious and ethical teachings that are conveyed during the process and during the sentence; 2 . The therapist only helps open the gap, and the possibilities of other ways, besides the way the client has been living; 3. Assist clients/actors in generating insight; 4 . Stimulate the client to be able to feel what the victim is feeling, Example: "How long are you going to be like this, going in and out of prison, don't want to see your daughter grow up?", "As a father, imagine one day your daughter is raped by someone else?", "Ever imagined that the most precious thing from you was taken away by someone else? "Ever imagined life outside prison" ; 5. Usually the obstacle faced is that the prisoners try to defend themselves as an attempt to justify what they have been doing so far, that's their business, yes, they are rich.[12] Mistakes in thinking can also lead to the emergence of a crime. Deviant behavior is based on a wrong understanding of how to meet basic needs and instincts. Irrational and destructive thinking can lead to emotional-behavioral disorders. However, the controversy surrounding the source of the emergence of errors of thought is still debated by scientists. Therefore, psychological programs related to their application in the field of law play a role in cognitive restructuring (correcting wrong ways of thinking). The roles often performed by psychologists in the legal field include:

\section{Psychologist as Advisor.}

In the court process the judge only considers the law, while in taking the consideration of punishment for some criminal cases it is necessary to have the opinion of a psychologist to provide information in determining the appropriate reasons for granting the sentence and in certain conditions psychologists can be an advisor to the perpetrators of the crime. 


\section{Psychologists as Evaluators.}

Without realizing it, a judge who decides in a divorce decision, children from divorced families will become victims. A judge needs psychological considerations to decide on a divorce, because the decision to divorce is the same as destroying a family. Therefore, psychologists in courts need to evaluate the competence of parents in terms of sole custody, regarding who is eligible to take care of the child.

3. Psychologists as Reformers.

In 2016 there were 259,150 cases of violence against women. A total of 245,548 cases were obtained from 358 Religious Courts and 13,602 cases were handled by 233 service procurement partner institutions spread across 34 provinces. Violence in the realm of issues still occupies the highest position. 245,548 cases of violence against wives that led to divorce. In the personal realm, Domestic Violence ranks first with 5,784 cases. Followed by violence in dating 2,171 cases, violence against girls 1,799 cases. [13] .

Criminals with unstable mental conditions need to be given in-depth counseling rather than just the law. From the victim's perspective, victims of violence should have a support system. The support system will help reduce the negative effects of the crime that the victim may experience. The support system is seeking moral assistance and psychological support from certain sources that are easily accessible and can be obtained when the victim needs it.

Werner even though in his book comparative law in the global context of the European, Asian and African systems states that legal studies should be directed to finding alternative perceptions of the world and of justice and various practices in solving practical problems, by accommodating conflicting interests while fulfilling the prerequisites of substantive justice. Legal issues relate to how we perceive and place ourselves in our environment. ${ }^{14]}$

\subsubsection{Implementation of Psychological Actions in Practice in Crime Cases.}

The attitude that needs to be taken by the examiner. Talking about the attitude of the examiner, actually cannot be separated from talking about a person's character. During the examination process, Inbau and Reid stated 12 (twelve) related to the attitude of the interrogator which was also applied by the investigators during the research, namely, as follows: First, Avoiding attitudes that could give the suspect the impression that the examiner was trying to obtain a confession. or to find fault. It is wisdom to present oneself as one who seeks to present the truth. Second, in the preliminary examination, the examiner should stay away from pencils and paper which are usually used as tools for taking notes. According to Inbau and Reid, such an attitude is to create an informal atmosphere so that the suspect feels that it is not tense and rigid. Third, firm terms such as "killing", "stealing", or "confessing or not" should not be used by the examiner. . Fourth, As is the case with the elements suggested in the second element above, it is considered beneficial if the examination is carried out without using a written table. Fifth, the examiner should not walk back and forth in the booth during the examination. Sit quietly, carry out the examination as a casual conversation. Sixth, the examiner should try as much as possible to reduce which cigarettes, make the inspected do the same. If the examiner wants to smoke too, he should start by presenting it first to the examinee. If the examiner intends to avoid smoking during the examination, it is better that the holder for cigarette ashes, matches and so on should be removed first. Seventh, use language that is easy to understand. On the other hand, if the examiner uses the local language, the examiner must be as wise as possible to draw conclusions and understand them. Eighth, the examiner should always try to respect the person being examined, no matter what the deed he has done. Ninth, When the examination finds that the examiner is lying, do not immediately criticize him by saying "why are you lying in front of me?" it is wise to hide reactions that cause disappointment. Tenth, if the examiner feels the need for an atmosphere without tension and fear during the examination, it is better if the examinee is not subject to shackles during his presence. Eleventh, the examiner must be able to place himself in the shoes of the person being examined. By this, Inbau and Reid mean that an examiner must be able to feel, if he is the one being examined. If it can be felt that way, the examiner will be able to feel how the person being examined thinks, how he will react, what words he will use. Twelfth, see that the person being examined is a human being with human characteristics. Don't look at it as a game, let alone view it as an object that all examiners think can be formed. [15]

In the investigation process there are tactics and techniques in examining suspects, namely first, tactics and techniques for examining suspects whose faults are clear and second, tactics and techniques for examining suspects whose faults are not yet clear. These tactics and techniques include the following: dealing with suspects whose faults are not yet clear, requires more psychological approaches. The tactics and methods that have been used in the examination have not been able to show who the perpetrators are who can be found guilty, then the method of deceiving the suspect can be used and in this case the use of psychology is evident in the investigation of a criminal case.

With the punishment in the form of a penal given to the perpetrators of the crime does not make the perpetrators a deterrent. Especially the perpetrators of sexual violence who accounted for the most recidivists, believed that imprisonment or punishment was a reward for some of them (the perpetrators of sexual violence who were caught). The challenges/enjoyments behind it all could overcome their fear of the threat of punishment. However, there is a need for psychological actions that must be taken for perpetrators to change 
their criminal behavior and be able to overcome the crime rate with a psychological action approach.

\section{CONCLUSION}

The role of psychological actions that can be taken in tackling crime is to carry out CBT cognitive restructuring activities, in which these activities are carried out in the form of; 1. Regarding efforts to straighten out the thinking of criminals who are 'already' wrong, this activity aims to provide a stimulus to the community, both perpetrators and defendants by providing religious and ethical teachings that are conveyed during the process and during the sentence2. The therapist only helps open the gap, and the possibilities of other ways, other than the way the client has been living; 3. Assist clients/actors in generating insight;4. Stimulate the client to be able to feel what is felt by the victim, Example: "How long are you going to be like this, going in and out of prison, don't want to see your daughter grow up?", "As a father, imagine one day your daughter is raped by someone else?", "Have you ever imagined that the most precious thing from you was taken away by someone else? "Have you ever imagined life outside a prison?" Mistakes in thinking can also lead to the emergence of a crime. Deviant behavior is based on a wrong understanding of how to meet basic needs and instincts. Irrational and destructive thinking can lead to emotional-behavioral disorders. However, the controversy surrounding the source of the emergence of errors of thought is still debated by scientists. Therefore, psychological programs related to their application in the field of law play a role in cognitive restructuring (correcting wrong ways of thinking).

The implementation of psychological action in the practice of criminal cases, namely in handling the examination process and even in the punishment of later carrying out psychological actions such as, Talking about the attitude of the examiner, actually cannot be separated from talking about a person's character. When the examination process takes place related to the attitude of the interrogator which is also applied by the investigators at the time of the research, it must use a psychological approach such as; in the investigation process there are tactics and techniques in examining suspects, namely first, tactics and techniques for examining suspects whose faults are clear and second, tactics and techniques for examining suspects whose faults are not yet clear. These tactics and techniques include the following: when dealing with suspects whose faults are not yet clear, more psychological approaches are needed.

\section{ACKNOWLEDGMENT}

The author would like to thank all parties who have supported this research so that this research can be completed properly. The author also expresses special thanks to the Doctoral Program in Law, Universitas
Sumatera Utara, which has supported the author, so that this research can be published in international journals.

\section{REFERENCES}

[1] Fiat Justitia Jurnal Ilmu Hukum Volume 6 No. 1 Januari-April 2012, ISSN 1978-5186 Aspek Kriminologis Dalam Penanggulangan Kejahatan Saleh Muliadi.

[2] Barda Nawawi Arief, Masalah penegakan Hukum dan Kebijakan Hukum Pidana Dalam menanggulangi Kejahatan, Kencana Pernada Media Group, Jakarta 2007, hal.81

[3] Barda Nawawi Arief, Masalah penegakan Hukum dan Kebijakan Hukum Pidana Dalam menanggulangi Kejahatan, Kencana Pernada Media Group, Jakarta 2007, hal.81

[4] Soerjono Soekanto dan Sri Mamuji, Penelitian Hukum Normatif "Suatu Tinjauan Singkat", PT Raja Grafindo Persada, Jakarta, 2004, hal. Dan lihat juga Ronny Hanitijo Soemitro, Metodelogi Penelitian Hukum dan Jurimetri, Ghalia Indonesia, Jakarta, 1990), hal. 12.

[5] Abintoro Prakoso, Ibid, hal 27.

[6] Rahayu dalam http:/ dolphinputihqiya. blogspot.com/2011/08/psikologi hukum.htlm diakses tanggal 13 Maret 2021 pukul 20.22 WIB, dalam Abintoro Prakoso, 2014, Hukum dan Psikologi Hukum, Raja Grafika, hal.28.

[7] Soerjono Soekanto, Beberapa catatan tentang psikologi hukum, Alumni, Bandung, 1979, hal 9.

[8] Soerjono Soekanto, Beberapa catatan tentang psikologi hukum, Alumni, Bandung, 1979, hal 9.

[9] Bahan Ajar Program Studi Psikologi Fakultas Kedokteran UNIVERSITAS UDAYANA 2016, hal, 36 .

[10] Barda Nawawi Arief, Tujuan Dan Pedoman Pemidanaan dalam Konsep RUU KUHP, Disusun untuk penerbitan Buku Kenangan/Peringatan Ulang Tahun ke 70 Prof. H. Mardjono Reksodiputro, SH, MA, Badan Penerbit FH UI, edisi I, Maret 2007.

[11] Teaching Materials for Psychology Study Program, Faculty of Medicine UNIVERSITAS UDAYANA 2016, op.,cit, hal, 36.

[12] Bahan Ajar Program Studi Psikologi Fakultas Kedokteran UNIVERSITAS UDAYANA 2016, op.,cit, hal, 36.

[13] Lutfy Mairisal Putra, Tahun 2016 Ada 259.150 Kasus Kekerasan Terhadap Perempuan, http://nasional.kompas.com/read/2017/03/07 /19240821/2016.ada.259.150.kasus.kekerasa n.terhadap.perempuan. diakses 28 Juni 2017 
[14] Werner Menski, Perbandingan Hukum Dalam Konteks Global, Bandung, Nusa Media, 2018, hal 5.

[15] G.W Bawengan, Penyidikan Perkara Pidana dan Teknik Interogasi ,PT. Pradnya Paramita, Jakarta, hal 89 . 